Izabela Felczak

\title{
INCREASE OF INITIAL CAPITAL OF A JOINT STOCK COMPANY IN THE LIGHT OF THE AMENDMENT OF POLISH TAX LAW
}

The increase of initial capital of a joint stock company in accordance with its Articles and the provisions of the Commercial Companies' Code ${ }^{1}$ may be conducted by means of the issue of new stock, the transfer of the generated net profit to this capital and by transferring other reserve funds and supplementary capital to the initial capital. The increase of initial capital with respect to tax law is governed by the provisions of the Corporate Income Tax Act of $15^{\text {th }}$ February $1992^{2}$ and the Goods and Services Tax Act (VAT) of $11^{\text {th }}$ March $2004^{3}$. Despite the fact that the tax classification of expenses associated with the increase of initial capital plays a significant role in the decision-making process of managing bodies, it still causes a number of problems for them. It must be stressed that there is no unanimity between the academic world and tax practice as to the interpretation of tax rules regarding the increase of the initial capital of a joint-stock company.

\section{Increase of initial capital by means of the issue of new stock}

In accordance with the regulations in force until the end of 2006, that is, with Article 15 (1) of the cited Corporate Income Tax Act, allowable expenses were only deemed to be expenses borne for the sole purpose of generating revenue (with the exception of expenses listed exhaustively under Article 16 (1) of the cited Act. According to the uniform view of tax law doctrine, in order for a company expense to be recognized as an expense for generating revenue, there must be, inter alia, a close causal connection between the expense in question and the generated revenue of this type, so as the bearing of the expense resulted in the generating or increase of revenue. The amended provision of Article 15 (1) of the Act provides

Journal of Laws No. 94, item 1037, as amended

Journal of Laws No. 21, item 86, as amended

Journal of Laws No. 54, item 535, as amended 
that allowable expenses are expenses borne for the purpose of generating revenues or for maintaining or securing the source of revenue. The expanded definition of allowable expenses introduced in 2007 is of a technical nature, and merely involves the accurate definition of the expediency of bearing costs ${ }^{4}$, as understood in already existing case-law and tax law doctrine.

By invoking the wording of the above provision, one can define the conditions which must be satisfied for an expense to be classified as allowable expenses ${ }^{5}$ :

1. The tax-payer has incurred the expense and it is genuine;

2. The expense borne by the tax-payer is closely connected with the subject of the conducted business;

3. The expense is borne for the purpose of generating revenues, or for maintaining or securing the source of revenue, as well as that it may have an impact on the magnitude of yielded revenues.

Therefore, bearing the above in mind, may expenses associated with the issue of stock, that is, financial consultancy and legal expenses, administrative expenses associated with the preparation of an issue prospectus (certified accountants' analyses) and the expenses of conducting the whole issuing procedure incurred by the company, be classified as the company's allowable expenses?

When a company decides to issue stock as one of the forms of financing the capital of its assets, it intends to solicit funds that are indispensable for achieving the planned targets (capital expenditures), which will enable, inter alia, an increase of the sales of products and the acquisition of new markets by the company. The achievement of this target involves the solicitation or securing of the company's source of revenue. Therefore, the soliciting of funds by means of the issue of new stock is also associated with the company's business, the results being taxable.

Until the end of 2006, numerous problems and divergences existed in the interpretation of tax law, both in case-law, as well as among the representatives of tax law doctrine, which were noticeable in numerous decisions issued by tax authorities at the taxpayers' motion.

Tax authorities had often refused the classification as allowable expenses of expenses associated with the preparation and implementation of increasing initial capital by means of issuing new stock, invoking, inter alia, the wording of Article 12 (4) (4) of the Corporate Income Tax Act, according to which revenues do not

\footnotetext{
$4 \quad$ Hellwing, Zmiany w podatku dochodowym od osób prawnych (Changes in corporate income tax), Monitor Podatkowy (Tax Monitor), 1/2007, p. 11.

5 R. Kubacki, Koszty uzyskania przychodów w podatkach dochodowych (Allowable costs and income taxes), UNIMEX, Warsaw 2005, p. 23.
} 
cover the so-called revenues received for the purpose of creating or increasing initial capital. Therefore, the expenses incurred as a result of issuing stock are not allowable costs, as they are associated with revenue not subject to income tax. ${ }^{6}$ Unfortunately, this view is still held by some tax authorities. ${ }^{7}$ To the author's mind, this view is misguided, as if one were to follow up on this analysis, it would have to be assumed that, for example, expenses associated with the obtaining of a loan facility by the company should not be classified as allowable expenses because the funds obtained under a loan facility are not classified as revenue subject to taxation.

For quite some time, the interdependence of the issue of stock and the business has been noted by a growing number of tax authorities. An example is the just decision of an appeals body, delivered even before $2007^{8}$, where it was held that pursuant to Article 15 (1) of the cited Act, one may classify as allowable expenses all expenses that are both indirectly and directly associated with generating revenue under the stipulation that the company (tax-payer) shall demonstrate its connection with the conducted business, and the bearing of said expenses has or may have an impact on the magnitude of the achieved revenues. Moreover, the authority in question noted that the increase of the initial capital performs an economic function, as it provides a basis for securing creditors' rights, and for example, a guarantee of repayment of loan facilities granted to the company, which may genuinely cause increased revenues for the company.

The purpose of the amendment introduced in 2007 (which merely accurately defined the concept of allowable costs in Article 15 (1) of the cited Act) was to limit disputes regarding the classification of a wide range of expenses indirectly associated with future revenues achieved by the company - as allowable costs. Has this indeed happened?

Following an analysis of a number of decisions delivered since 2007 regarding the interpretation of tax law, and concerning the possibility of classifying expenses associated with increasing initial capital by means of issuing new stock as allowable costs, one can observe a constantly increasing uniformity. The amendment dated $29^{\text {th }}$ August, 1997, of the Tax Code (Journal of Laws No. 8, item 60, as amended) is also worth mentioning insofar as individual interpretations of tax law are concerned. The main premise of the introduced system is a centralization of providing binding written interpretations of tax rules. This will allow for the elimination of existing discrepancies in assessments of applying tax law in identical factual situations by the various tax authorities. Therefore, as tax interpretations did not form a uniform

6 Decision of the Second Mazowiecki Fiscal Office in Warsaw dated 28 ${ }^{\text {th }}$ June, 2006, ref. 1472/ROP1/423162/205/06/PK.

7 See also: Decision of the Third Mazowiecki Fiscal Office in Radom dated 09 ${ }^{\text {th }}$ August, 2007 ref. 1473/952/ KDO/423/60/07/JŻ.

8 Decision of the Fiscal Chamber in Łódź dated $17^{\text {th }}$ December, 2006, ref. III-3/4407int-75/VAT/06/TK. 
system of tax law interpretation, the legislature transferred the duty of delivering them to the central authority, that is, the competent minister for public finance. However, the legislature provided for an option of derogating from the total centralization of delivering interpretations, by authorizing the Minister of Finance to issue by way of a regulation, authorizations to subordinate authorities to deliver tax interpretations on behalf of the central authority. The Minister of Finance has exercised this right and authorized four Fiscal Chambers: in Bydgoszcz, Katowice, Poznań and Warsaw. It must be stressed that the authority which delivers an interpretation has the statutory duty to take into account the case-law of courts, the Constitutional Court and the European Court of Justice.

Unfortunately, problems also exist with the interpretation of the Goods and Services Tax Act (hereinafter, VAT). They concern the possibility of deducting input tax during the purchase of goods and services associated with the issue of stock. Polish tax practice has also failed at unanimous interpretation in this case. As an example, by its decision, the Fiscal Chamber in Lublin has held ${ }^{9}$ that a company cannot exercise its right of deduction of input tax, as, pursuant to Article 86 (1) of the VAT Act, one is entitled to it insofar as the goods and services are used to perform taxable transactions. "The issue of stock is neither a supply of goods or providing of services within the territory of the state within the meaning of Article 7 (1) and Article 8 (1) of the cited Act". This being the case, issue of stock does not fall under transactions subject to the VAT tax. ${ }^{10}$

In a similar factual situation, the Fiscal Chamber in Wrockaw delivered a different decision. ${ }^{11}$ According to the statement of reasons, the issue of stock does not fall under the subject matter of the cited Act, and it is not a delivery of goods or providing of services within the meaning of Article 7 (1) and Article 8 (1) of the VAT Act. However, in accordance with Article 86 (1) of this Act, "In principle, the taxpayer is entitled to decrease the amount of the output tax by the amount of the input tax" in connection with the use of purchased goods and services for conducting taxable transactions. To the Chamber's mind, it is essential that there is a relevant connection (both direct and indirect) between purchases and the conducted business, the effects of which are taxed under the VAT Act. ${ }^{12}$ Therefore, it is to be understood that the above connection also pertains to such transactions - which despite being exempt from tax liability - are necessary for the conduct of the taxpayer's statutory business.

The cited example and the method of analysis of the above-cited rules are just. If the issue of stock had a clear connection with the subject of business, and its

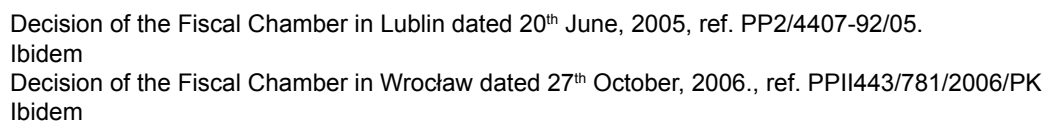


purpose was company development, then the expenses associated with such business operations bear an impact on the company's future revenue. It must also be stressed that the decision of the Fiscal Chamber in Wrocław, which made it possible for the tax-payer to exercise his right of deduction of input tax, is in line with the judgment of the European Court of Justice in Case C-465/03 (Kretztechnik AG v Finanzamt Linz). ${ }^{13}$

\section{Increase of initial capital by means of capitalization of reserves}

The capitalization of reserves involves the increase of initial capital by a transfer of funds from other capitals, that is, either from the company's supplementary capital or reserve capital. In this case, the amount by which the initial capital will be increased - in accordance with Article 10 of the Corporate Income Tax Act - constitutes income for the stockholders from sharing in the profits of corporations. Apart from the aforementioned net profit, another source of creating the supplementary capital may also be the surplus resulting from the issue of stock, which constitutes the difference between the issue price of the stock and the price for which the stock has been taken over, and it is this form of increase which is most controversial in tax law practice.

According to Article 24 (5) (4) of the Corporate Income Tax Act, "income from sharing in the profits of corporations is also the income which constitutes the value of amounts transferred to the initial capital from other capitals of the corporation." Therefore, tax authorities are of the view that "it is irrelevant as to how the supplementary capital has been created." Every transfer of funds from the supplementary capital to the initial capital gives rise to tax liability for the current stockholders. ${ }^{14}$ The Supreme Administrative Court has expressed this view in its ruling dated $20^{\text {th }}$ January, 2005. ${ }^{15}$

However, the prevailing view in tax law doctrine - upon invoking the wording of Article 12 (4) (11) of the cited Act - that the amounts which constitute a surplus above the stock's nominal value (so-called agio or premium), received at the time of their issue and transferred to the supplementary capital - are not classified as revenue. ${ }^{16}$ It must further be recognized that "income equal to the value of amounts transferred to the initial capital from other capitals of the corporation, may only be treated as income from sharing in the profits of corporations if it falls within the concept of

\footnotetext{
13 Judgment of the European Court of Justice of 25 $25^{\text {th }}$ May, 2005 in Case C-465/03 Kretztechnik AG v Finanzamt Linz

14 Letter of the Ministry of Finance dated $10^{\text {th }}$ March, 1997, ref. PO 4/AS-822-112/97, Biul. Skarb.(Treasury Bulletin) $3 / 2003$, p. $39-42$

15 Judgment of the Supreme Administrative Court dated $20^{\text {th }}$ January, 2005, File no. FSK 1065/04

16 J. Marciniuk, Podatek dochodowy od osób prawnych (Corporate Income Tax), editor, CH BECK, Warsaw 2005, p. 168
} 
income actually derived from this sharing", and therefore when the transfer of funds from supplementary capital may be deemed to be a form of stockholder participation in the entity's profits. ${ }^{17}$ For this reason, agio cannot be classified as funds which constitute profit generated by the company, as these are funds originating from its stockholders. The Supreme Administrative Court shares this view ${ }^{18}$ and held that the increase of share capital by means of capitalizing reserves only gives rise to tax liability if the supplementary capital originates from undistributed company profits during previous years. In the justification of this judgment, the Court rightly draws attention to functional considerations. Pursuant to the provisions of the Commercial Companies' Code, supplementary capital is supplied by the so-called issue agio, and in accordance with Article 16 (1) (8) of the Corporate Income Tax, expenses for taking over stock are covered from the profit, after taxes. By the same token, the issue surplus is created from funds which constitute profit after taxes. The taxation of the very same funds with income tax would effectively lead to double taxation of the same income. It must further be stressed that in light of Article 26 (1) of the Corporate Income Tax Act, the company will be the payer of the tax in this instance. It follows from Article 8 of the Tax Code that the payer is responsible for calculating the amount of the tax, its collection from the stockholders and for paying it to the tax authority. This is most difficult, especially in the case of companies which issue bearer shares, or which have very dispersed stockholders or in the case of public companies. ${ }^{19}$ Accordingly, the performance of the company's duty to collect the tax from stockholders is impracticable.

The increase of initial capital is a process conducted by a great number of joint stock companies. Despite the above, Polish companies still face grave problems in connection with implementing this process, and ask themselves numerous questions against the background of tax law. This is caused by a lack of a uniform position on part of tax authorities in tax practice, as well as in case-law. A lack of communication between tax practices applied by tax authorities and representatives of tax law doctrine is a most adverse phenomenon. Despite critical opinions expressed by tax practitioners and tax law doctrine, solutions introduced by the legislature are not amended. Until 2007, tax law interpretations were delivered by over 400 tax institutions, and the assessment of applying tax law in identical factual situations significantly differed. However, as of 2007 , four tax chambers were authorized to deliver tax interpretations, which have had a positive impact on the quality and uniformity of assessing the application of tax law, which will allow taxpayers to make a closer evaluation of the advantages resulting from their choice of the form of financing assets.

\footnotetext{
17 D. Strzelec, Podwyższenie kapitału zakładowego w drodze kapitalizacji rezerw ( Increase of initial capital by means of capitalizing reserves), Monitor Podatkowy (Tax Monitor) 11/2006, p. 29.

18 Judgment of the Supreme Administrative Court dated $5^{\text {th }}$ July, 2002, File No. ISA/Kr 1625/00

19 Ibidem
} 


\section{Streszczenie}

Podwyższenie kapitału początkowego spółki akcyjnej zgodnie z przepisami prawa spółek handlowych może być przeprowadzone poprzez emisję nowych akcji, transfer wygenerowanego zysku netto na rzecz tego kapitału oraz transfer innych funduszy rezerwowych i kapitału uzupełniającego na rzecz kapitału początkowego. Pomimo faktu, że czynności dokapitalizowania są dosyć częste, polskie spółki stają przed poważnymi problemami dotyczącymi obowiązków podatkowych w tym zakresie. Klasyfikacja kosztów dla celów podatkowych związanych ze wzrostem kapitału początkowego odgrywa znaczącą rolę w procesie podejmowania decyzji przez organy zarządzające spółek i ciągle powoduje wiele problemów.

Celem opracowania jest zaprezentowanie wstępnej oceny zmian ustawy o podatku dochodowym o od osób prawnych i Ordynacji podatkowej wprowadzonych w tym zakresie w 2007 roku. 